\title{
AGRICULTURAL ADVISORY SERVICES IN THE PROCESS OF SHAPING ENTREPRENEURIAL ATTITUDES
}

\author{
Wioletta Bienkowska-Golasa ${ }^{1}, \mathrm{PhD}$; Anna Justyna Parznko ${ }^{2}, \mathrm{PhD}$; Anna Sieczko ${ }^{3}$, PhD \\ $1,2,3$ Warsaw University of Life Sciences - SGGW
}

\begin{abstract}
The main aim of paper was to present the activities of agricultural advisory centres aimed at the encouragement of entrepreneurship and promotion of non-agricultural functions in the rural areas. The study involved the analysis of documents made available by the Ministry of Agriculture and Rural Development regarding the activity of agricultural advisory units in 2017 and mass statistics data provided by the Central Statistical Office. The basic tasks of agricultural advisory centres aimed at improving the competitiveness of the Polish agricultural sector, enhancing the quality of life in rural areas and improving professional qualifications of rural residents in Poland. Under the Common Agricultural Policy for 2014-2020, special measures have been taken to encourage farmers to set up their own business. The most important activities, also shaping entrepreneurial attitudes, aimed to support the development of small family businesses in the fields of agritourism, rural tourism, educational farms, small-scale on-farm processing and marketing of the manufactured products through short distribution chains (e.g. in the form of marginal limited local business), agricultural retail trade as well as direct sales and direct deliveries including labelling of packaged food.
\end{abstract}

Key words: entrepreneurship, agricultural advisory services, entrepreneurial attitudes.

JEL code: R11.

\section{Introduction}

Entrepreneurship is one of the economic and social categories, which constitutes a key element under all political conditions, both domestic and international, and at every stage of civilization and economic development of a given society (Bienkowska W., 2013). In economic terms, entrepreneurship is perceived as the drive to search for and implement new forms of development which can contribute to the quality of life of particular social groups (e.g. farmers), civilization progress, and increase in affluence of individuals or change in social status. Thus, the economic growth of rural areas is closely related to the development of various forms of entrepreneurship both in the individual and collective dimension (Parzonko A. J. Sieczko A., 2018). The concept of collective entrepreneurship can be understood as organized, conscious and voluntary cooperation of people focused on the achievement of a common goal, e.g. thanks to the pooling of funds, reduction of production costs (effect of scale and scope), increase of the impact on the market (increase in market share) (Parzonko A. J., 2012). Therefore, the interrelations of economic processes and phenomena that may affect entrepreneurs seem to be important, and at the same time contribute to increased diversity of products and services provided by them (Golasa P., 2013).

A. P. Wiatrak argues that "entrepreneurship can be treated as an attitude or as a process of changes resulting from this attitude". According to him, entrepreneurship as an attitude is a feature characteristic of human individuals, expressing itself in creative and active behaviour towards the surrounding reality focusing on improving the existing elements of the environment. It manifests itself in undertaking new activities or expanding the existing ones and aiming to achieve the assumed material benefits (Wiatrak A., 1998). Therefore, in order to encourage entrepreneurship a group of certain traits should be formed through appropriate upbringing or education, which will facilitate the undertaking of various entrepreneurial activities. According to Gibb (Gibb A. A., 1993) these features include: initiative, persuasiveness, rather moderate than high tolerance to risk, flexibility, creativity, 
independence/autonomy, problem-solving ability, need for achievement, imagination, belief in one's control of one's own destiny, leadership and the ability to work hard. Considering the entrepreneurial attitudes of Polish individual farmers in the historical context, one can identify a group of characteristic features typical of this social group, i.e.: diligence, thriftiness, resourcefulness, aversion to coercion (that is, love of individual freedom) and independence (Styk J., 1998). These features predisposed farmers to actively cope with new socio-economic changes in Central Europe after 1989 , which at that time led to the impoverishment of rural families and an increase in both official and hidden unemployment (Rak A., Multan E., 2015). Undertaking attempts to reduce unemployment or increase income from agricultural activity, part of individual farmers in the $90 \mathrm{~s}$ of the twentieth century decided to expand agricultural activities with services closely related to agriculture like food processing or agritourism (Balinska A., Zawadka J., 2013). Others diversified out of agriculture to create enterprises operating in rural areas.

When it comes to shaping and supporting entrepreneurial attitudes towards creativity and innovation Polish farmers owe a lot to agricultural advisory centres. These units did not only shape entrepreneurial attitudes among farmers, but also undertook actions to increase agricultural income, improve the market competitiveness of farms, support sustainable rural development and improve professional qualifications of farmers and other rural residents (Journal of Laws of 2013, item 474). The advisory centres had considerable merit in encouraging farmers to set up their own business. It resulted from the Common Agricultural Policy for 2014-2020, where the development of entrepreneurship was the main priority in multifunctional rural development but also the response to unfavourable demographic processes: aging and disappearance of rural areas and migration of rural population to cities (Parzonko A. J., 2013). Institutional support for rural entrepreneurship alongside economic, cultural and environmental factors may contribute to its development or constitute a development barrier (Skubiak B., 2015).

To sum up, the term entrepreneurship refers to both economic activity and other forms of human activity, where creativity, initiative, and simply entrepreneurship are required. Entrepreneurship is conditioned by personality factors (such as personality traits, professional competences and motivation), social factors (e.g. social acceptance and recognition for such behaviour) or economic factors (financial possibilities, institutional support, etc.). In order to release the potential necessary for entrepreneurial activities it is necessary to foster knowledge transfer in the field of management, marketing, economics, finances or computer skills, always with an emphasis on gaining practical skills (Sieczko A., Parzonko A. J., 2017). Entrepreneurship becomes a "way of life" for all participants of the market economy, both households and business units. It is the market that enforces this situation, becoming a natural creator of entrepreneurial behaviour in the market economy (Bienkowska-Golasa W., 2015).

The main aim of paper was to present activities of agricultural advisory centres aimed the development of entrepreneurship and non-agricultural functions in the rural areas. The research task was to analyze documents made available by the Ministry of Agriculture and Rural Development regarding the activity of agricultural advisory units in 2017 and mass statistics data provided by the Central Statistical Office. Additionally, the study includes the review of literature on economic and social conditions of entrepreneurship in rural areas. 


\section{Research results and discussion}

The activity of agricultural advisory centres is mainly focused on increasing the competitiveness of the Polish agricultural sector, enhancing the quality of life in the rural areas, and improving the professional qualifications of rural residents in Poland. The objectives set by individual advisory centres resulted from the development strategies drawn up for particular regions, the programs for the development of agriculture and rural areas as well as the current needs and expectations of the local community. Advisory services are flexible; they adapt to new challenges and play an important role in the transformation of rural areas and agriculture.

Pursuant to the Act on Agricultural Advisory Units, the establishment of agricultural advisory centres was aimed at providing assistance to farmers and residents of rural areas, primarily through free-of-charge activities as well as commercial ventures (Journal of Laws no. 251, item 2507). The objectives that agricultural advisory centres implemented in 2017 included inter alia: raising awareness in the field of bio security, healthy food and renewable energy sources, ensuring the greatest possible participation of farmers in new programmes proposed under the Rural Development Program 2014-2020, encouraging entrepreneurship in rural areas - on-farm processing and direct sales, improvement of the quality of life of rural residents, fostering knowledge transfer and innovation, improving the competitiveness of farms, popularization of integrated production methods, implementation of good agricultural practices, proposing the best technological, organizational and economic solutions on farms, raising ecological awareness, popularizing a healthy lifestyle, preserving cultural heritage, popularizing group activities in rural areas and the activation of the rural community.

Table 1

Selected data regarding the operations of Agricultural Advisory Centres in 2017

\begin{tabular}{|l|c|c|c|c|}
\hline $\begin{array}{c}\text { Agricultural Advisory } \\
\text { Centre (AAC) by } \\
\text { voivodeship }\end{array}$ & $\begin{array}{c}\text { Number of } \\
\text { staff employed } \\
\text { by AAC }\end{array}$ & $\begin{array}{c}\text { Number of } \\
\text { staff employed } \\
\text { as field } \\
\text { advisors }\end{array}$ & $\begin{array}{c}\text { Number of } \\
\text { farms per one } \\
\text { field advisor }\end{array}$ & $\begin{array}{c}\text { Number of } \\
\text { trainings } \\
\text { provided in 2017 }\end{array}$ \\
\hline Dolnoslaskie & 239 & $189(163)$ & 343 & 1326 \\
\hline Kujawsko - pomorskie & 259 & $186(121)$ & 527 & 1199 \\
\hline Lubelskie & 327 & $289(231)$ & 779 & 1200 \\
\hline Lubuskie & 131 & $79(56)$ & 361 & 326 \\
\hline Lodzkie & 257 & $208(156)$ & 795 & 1459 \\
\hline Malopolskie & 199 & $174(145)$ & 964 & 711 \\
\hline Mazowieckie & 542 & $316(291)$ & 731 & 1854 \\
\hline Opolskie & 108 & $83(54)$ & 490 & 387 \\
\hline Podkarpackie & 302 & $247(199)$ & 667 & 874 \\
\hline Podlaskie & 213 & $180(145)$ & 560 & 515 \\
\hline Pomorskie & 208 & $174(98)$ & 398 & 900 \\
\hline Slaskie & 181 & $133(97)$ & 562 & 973 \\
\hline Swietokrzyskie & 193 & $139(93)$ & 917 & 776 \\
\hline Warminsko-mazurskie & 179 & $147(112)$ & 385 & 3303 \\
\hline Wielkopolskie & 359 & $316(262)$ & 462 & 1237 \\
\hline Zachodniopomorskie & 181 & $145(100)$ & 296 & 18503 \\
\hline Total & 3878 & $3005(2323)$ & 607 & \\
\hline Source: Ministry of Agriculture and Rural Development and Central Statistical Office & \\
\hline
\end{tabular}

Table 1 presents key numerical data characterizing the farm advisory system in Poland. In 2017, 3005 people were employed in agricultural advisory centres in positions of advisors, of which 2,323 people were employed as a field advisor who is responsible for providing advisory services 
directly in the field. As can be seen from the data included in Table 1 in Poland, there are on average 607 farms for one field advisor. Shortage in manpower motivates the staff to look for alternative (other than individual consultation) ways of providing rural residents with support and information. The most popular form of providing advice in the last decades has become training, thanks to which it is possible to transfer knowledge to larger recipient groups. The trainings provided by agricultural advisory centres are addressed to farmers and residents of rural areas. At the same time, special attention is paid to tailor the educational offer to the expectations of the recipients of services. In 2017 the number of trainings provided nationwide was 18503.

Agricultural advisory centres as business support institutions served the existing and potential entrepreneurs by providing advice on setting up a business, gaining or upgrading employees' qualifications, creating new jobs, cost rationalization, etc. It is even more important that rural areas in most regions of Poland are characterized by large and insufficiently used manpower resources, also in agriculture, with a low profitability for rural residents. The development of entrepreneurship and increasing investment attractiveness is a way to enhance economic activity in the countryside and create additional sources of income. One of the priority areas defined by the Ministry of Agriculture and Rural Development is encouraging entrepreneurship and developing non-agricultural functions of the rural areas, including:

A - support for farmers in undertaking and developing non-agricultural activities,

B - promotion of regional and local products and quality systems,

C - transfer of knowledge concerning small-scale food production and marketing of food products in short distribution chains, including information about marginal, local and limited business activity, agricultural retail trade and direct selling,

D - providing information on the possibilities of rural development with the use of EU funds,

E - promoting agricultural producer groups and their associations, producer organizations and their associations as well as inter-branch organizations (with particular emphasis on the cooperative form).

In Figures 1 and 2 and Table 2 included in the paper, priority actions have been marked accordingly.

Depending on the needs of farmers and residents of rural areas, agricultural advice (unpaid and paid tasks) was provided through various forms and methods, including: on-site and off-site trainings, conferences, shows, contests, consultations and demonstrations.

Figure 1 shows the number of on-site trainings, off-site trainings and demonstrations delivered in the priority areas. These are forms and methods of advisory work used by advisors to transfer knowledge and information necessary for effective functioning in the socio-economic environment, which also contributes to effective shaping the entrepreneurial attitudes of rural residents.

The support of farmers in diversifying into non-agricultural activities (A) most often took the form of assistance in the process of making the most economically justified decisions by preparing economic analyses of farm viability and farm production, which in consequence resulted in recommendations regarding favourable professional reorientation or improving professional qualifications. In this area, 26333 consultations were provided and 271 on-site trainings as well as 63 off-site trainings were organized, in which 5853 people participated in total. Additionally, 125 demonstrations were performed. 


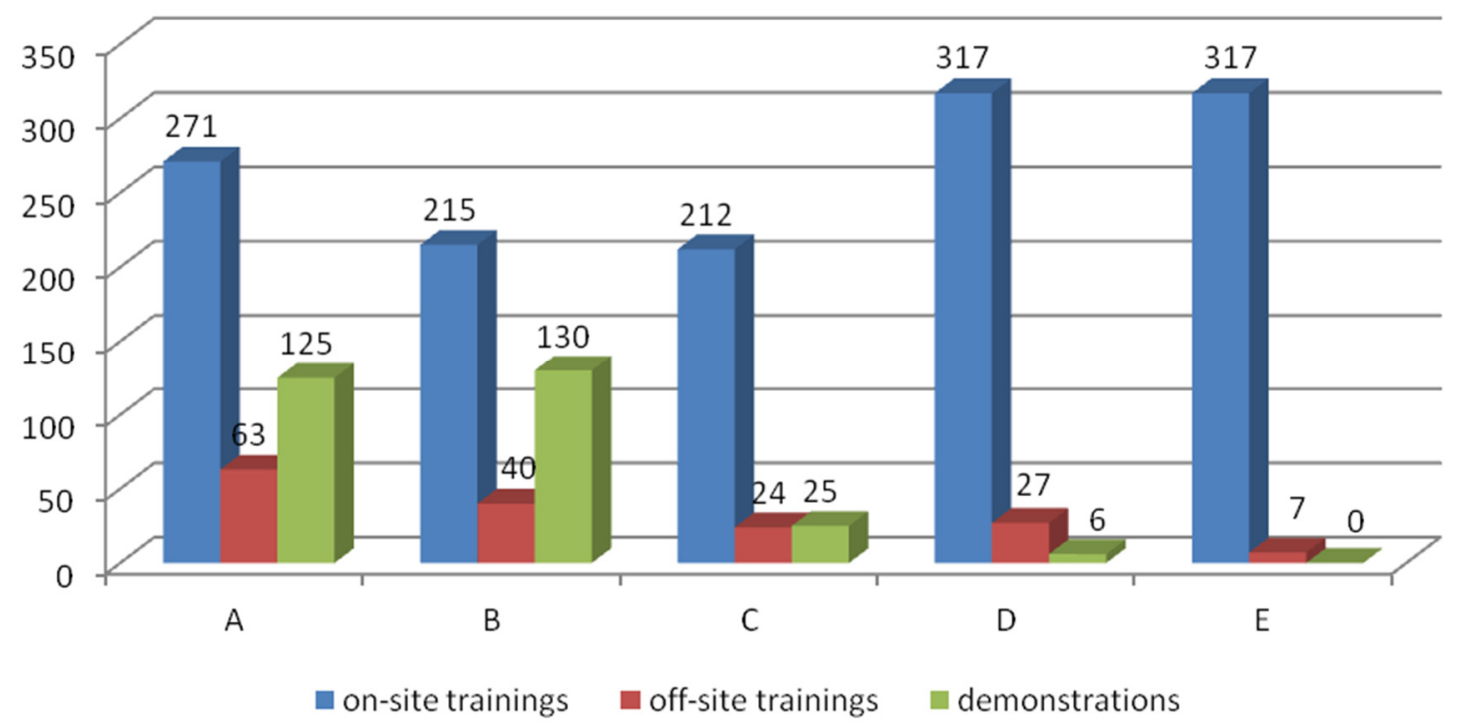

* priority actions have been marked accordingly $A, B, C, D$ i $E$.

Source: Annual reports on the operations of Agricultural Advisory Centres for 2017

Fig. 1. Number of on-site trainings, off-site trainings and demonstrations organized by agricultural advisory centres in $\mathbf{2 0 1 7}$

One of the ways to implement the quality policy is granting signs confirming the high quality of agri-food products from specific regions, as well as those manufactured with the use of a traditional production method. In order to promote regional and local products and quality certification (B) 255 trainings were organized (40 of them were off-site trainings) as well as 130 shows and tastings. They aimed at rising consumers' awareness of the impact of food on health and quality of life and stimulating their interest in high quality products. Promotion and popularization of such food products creates the opportunity to sell and buy the sought after high quality products, but is also an important element of regional development.

Another area which agricultural advisors focused on was spreading knowledge about small-scale food processing and marketing the food products through short distribution chains, including the subject of marginal, local and limited business activity, agricultural retail trade and direct sales (C). Each poviat agricultural advisory team employs advisors for rural households and agritourism, whose main tasks in 2017 were not only to provide information on regional and local products, but also small-scale production of food and marketing it (in total 15311 consultations were held in this area). Additionally, 236 trainings were provided to inform farmers about legal regulations as well as amended definitions referring to the farmers' ability to sell their food, in which 3,544 people participated. These trainings covered such topics as: direct deliveries, direct sales, marginal, local and limited business activities as well as agricultural retail trade, including issues related to the labelling of packaged food intended for the consumer. Also, special activities were undertaken to promote local products by organizing 25 demonstrations and tastings during trade fair and exhibition events. The production, protection and promotion of high-quality food play an increasingly important role in the EU.

The availability of information on rural development opportunities with the use of EU funds (D) is very important for shaping entrepreneurial attitudes and decision making. Information has become one of the indispensable commodities nowadays and that is why accessing and using appropriate sources is so important (Jaska E., Werenowska A., 2018). This applies to every area of socioeconomic life, including agriculture and rural residents. The advisors focused particularly on such 
issues as supporting and promotion of agritourism farms or the creation and development of thematic villages. In this area, 354 trainings were delivered to approximately 5658 people and 35132 consultations).

Promotional activity related to the organization and functioning of agricultural producer groups was carried out through extensive information spreading activities (approximately 35132 consultations) and training (324 trainings for 5972 people) concerning the functioning of agricultural producer groups. They were aimed to show the need and possibilities for farmers' integration, inform about the support for producer groups available under Rural Development Policy 2014-2020, and thus encourage integration. Advisory services were also aimed at showing the benefits of cooperation, providing assistance in organizing founding meetings, setting goals for the group's activities, developing action programs and establishing contacts with other producer organizations in order to understand the specificity of the group's operation.

Forms and methods of advisory services provided in 2017 in the area of rural entrepreneurship

\begin{tabular}{|c|c|c|c|c|c|c|}
\hline \multicolumn{2}{|c|}{ Priority } & \multirow{2}{*}{$\begin{array}{c}\mathbf{A} \\
271\end{array}$} & \multirow{2}{*}{$\begin{array}{c}\text { B } \\
215\end{array}$} & \multirow{2}{*}{$\begin{array}{c}\text { C } \\
212\end{array}$} & \multirow{2}{*}{$\frac{\text { D }}{317}$} & \multirow{2}{*}{$\begin{array}{c}\mathbf{E} \\
317\end{array}$} \\
\hline troining & $\begin{array}{l}\text { Number of } \\
\text { events }\end{array}$ & & & & & \\
\hline салиту & $\begin{array}{l}\text { Number of } \\
\text { participants }\end{array}$ & 3993 & 3285 & 3323 & 5116 & 5828 \\
\hline \multirow{2}{*}{ conference } & $\begin{array}{l}\text { Number of } \\
\text { events }\end{array}$ & 11 & 9 & 7 & 13 & 10 \\
\hline & $\begin{array}{l}\text { Number of } \\
\text { participants }\end{array}$ & 729 & 451 & 487 & 745 & 557 \\
\hline \multirow{2}{*}{$\begin{array}{l}\text { off-site } \\
\text { training }\end{array}$} & $\begin{array}{l}\text { Number of } \\
\text { events }\end{array}$ & 63 & 40 & 24 & 27 & 7 \\
\hline & $\begin{array}{l}\text { Number of } \\
\text { participants }\end{array}$ & 1860 & 997 & 221 & 542 & 144 \\
\hline consultation & $\begin{array}{l}\text { Number of } \\
\text { participants }\end{array}$ & 26333 & 17772 & 15311 & 35132 & 18897 \\
\hline contest & $\begin{array}{l}\text { Number of } \\
\text { events }\end{array}$ & 92 & 29 & 1 & 6 & - \\
\hline demonstration & $\begin{array}{l}\text { Number of } \\
\text { events }\end{array}$ & 125 & 130 & 25 & 6 & - \\
\hline
\end{tabular}

* priority actions have been marked accordingly $A, B, C, D$ i $E$.

Source: Annual reports on the operations of Agricultural Advisory Centres for 2017

Advisors are involved in the organization of many fairs and exhibition events on a regional and national scale which promote agricultural activity as well address issues in the field of ecology, entrepreneurship and cultivating tradition. In the process of shaping entrepreneurial attitudes, activities such as organized contests, in which both knowledge and skills can be demonstrated, play an important role. The main purpose of these advisory methods is to shape the competitive attitude in achieving better and better results as well as active attitude in the search for new knowledge and information. Social benefits are also important, such as the increase in the prestige of people participating in such initiatives in the social environment or a boost to their self-esteem. The data presented in Table 2, show that most contests topics focused on non-agricultural sources of earning (92 contests) and local and regional products (29).

The increase in the level and quality of agricultural production and the functioning of agricultural holdings was supported by publishing activities. Each provincial agricultural advisory centre published 
monthlies, brochures, leaflets and information materials on a regular basis. The publications informed about changes in legal regulations and innovative solutions in agricultural production and in rural areas.

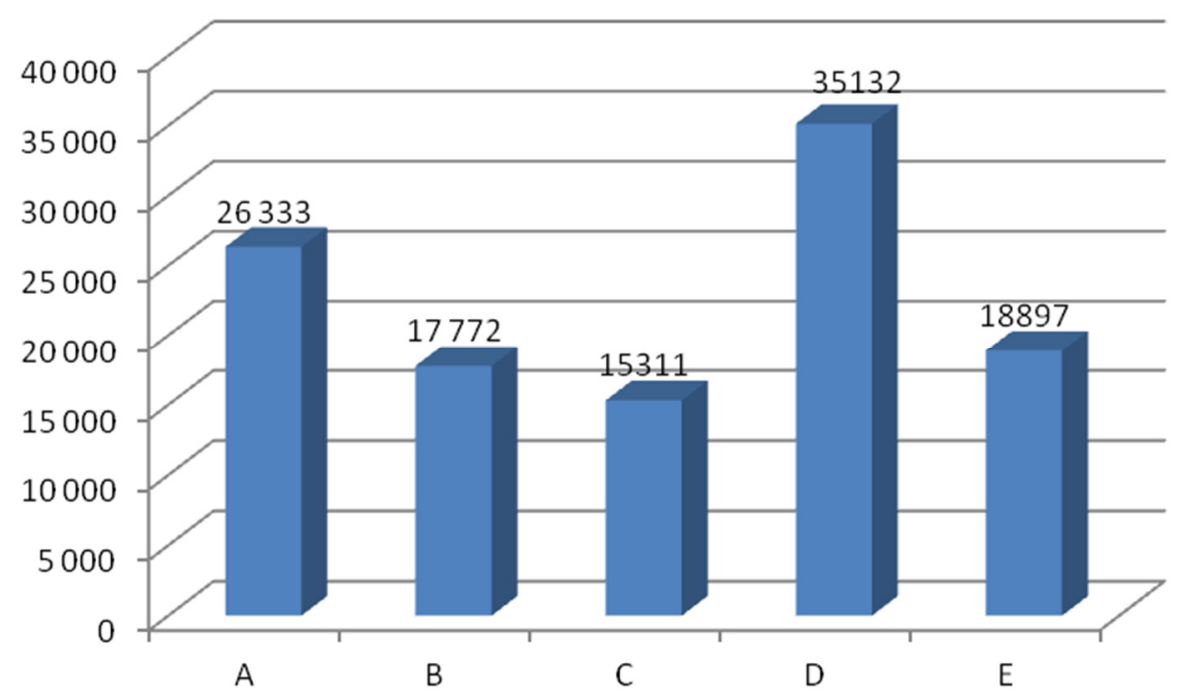

* priority actions have been marked accordingly $A, B, C, D$ i $E$.

Source: Annual reports on the operations of Agricultural Advisory Centres for 2017

Fig. 2. Individual consult ting by priority tasks (number of provided consultations)

The form of advisory services which is considered most effective is individual consultation, the basis of which is one to one cooperation between a consultant and an individual seeking advice. It allows the adviser to become involved in one person's situation and analyse it in depth. In 2017, advisors provided a total of 113445 individual consultations. Their expert advice mainly concerned issues related to setting up and expanding business activities as well as company development concepts with particular focus on the possibility of obtaining funds and available sources of funds for business investments, both for existing enterprises and for start-ups.

\section{Conclusions, proposals, recommendations}

1) Despite insufficient manpower agricultural advisory centres have the trust of the rural population, which was visible in the number of forms of support provided to farmers regarding setting up and development of non-agricultural activities, i.e. 26333 consultations, 334 trainings which in 2017 involved 5853 people.

2) The most important actions aimed at encouraging entrepreneurship and shaping entrepreneurial attitudes included support to the development of small family businesses in the areas of: agritourism and rural tourism, educational farms, on-farm processing on a small scale and marketing the products, short supply chains, agricultural retail trade as well as direct sales and direct deliveries including labelling of packaged food.

3) Appropriate funding should be secured for agricultural advisory centres to ensure the continuation of their activities to encourage rural entrepreneurship and shape entrepreneurial attitudes.

\section{Bibliography}

1. Balinska, A., Zawadka, J.(2013). Znaczenie agroturystyki w rozwoju obszarow wiejskich (The Role of Agritourism in Rural Development). Ekonomika i Organizacja Gospodarki Zywnosciowej. Zeszyty Naukowe Szkoły Głownej Gospodarstwa Wiejskiego w Warszawie No 102, pp. 127-144.

2. Bienkowska, W. (2013). Activities of Local Authorities in Pomoting Entrepreneurship in Poland. Economic Science for Rural Development. Jelgava: Issue: 32, p. 27. 
3. Bienkowska-Glasa, W. (2015). Entrepreneurship and Trends in Development of Rural Communes in Poland. Economic Science for Rural Development. Jelgava: Issue: 39, p. 108.

4. Gibb A.A. (1993). Enterprise Culture and Education: Understanding Enterprise Education and its Links with Small Business, Entrepreneurship and Wider Educational Goals. International Small Business Journal", Vol. 11, No.3, pp. 13-34.

5. Dziennik Ustaw Rzeczpospolitej Polskiej z dnia 19 kwietnia 2013 r, poz. 474 w sprawie ogloszenia jednolitego tekstu ustawy o jednostkach doradztwa rolniczego (Journal of Laws of the Republic of Poland of April 19, 2013, item 474 Regarding the Publication of a Uniform Text of the Act on Agricultural Advisory Units).

6. Golasa P. (2013). Taxes and Social Insurance Contributions Charges of Farms in Poland in the Years 2004-2008. Economic Science for Rural Development: Production and Cooperation in Agriculture / Finance and Taxes. Proceedings of the International Scientific Conference, Issue: 30, pp. 242-247.

7. Jaska, E., Werenowska A. (2018). The Availability and Use of Media Information Sources in Rural Areas. Economic Science for Rural Development. Jelgava: Issue: 47, p. 115.

8. Parzonko, A.J. (2012). Role of Leadership in Development of Group Enterprise. Proceedings of the International Conference on Management of Human Resources 2012, Management - Leadership - Strategy Competitiveness: Godollo Hungary 14-15 June: Vol. 1, pp. 249-251.

9. Parzonko, A. J. (2013). Funkcjonowanie obszarow wiejskich w warunkach depopulacji (Functioning of Rural Areas Under Depopulation Conditions), (In:) Budowanie konkurencyjności obszarow wiejskich [Building Competitiveness of Rural Areas], Krzyzanowska, K., (Ed.). Warszawa: Wydawnictwo SGGW, pp. 9-18.

10. Parzonko, A.J., Sieczko, A. (2018). Agricultural Producer Groups as Manifestation of Team Entrepreneurship in Poland. Economic Science for Rural Development. Jelgava: Issue: 47, pp. 221-228.

11. Rak, A, Multan, E. (2015). Przedsiebiorczosc rolnikow indywidualnych w Polsce - stan i kierunki rozwoju. (Entrepreneurship of Individual Farmers in Poland - Current State and Directions of Development). Zeszyty Naukowe Uniwersytetu Przyrodniczo-Humanistycznego w Siedlcach. Seria Administracja i Zarzadzanie No 107, p.176.

12. Sieczko, A., Parzonko, A.J. (2017). Przedsiebiorczosc pozarolnicza na obszarach wiejskich w wojewodztwie mazowieckim. (Non-Agricultural Entrepreneurship in Rural Areas in the Masovia Province). Zagadnienia Doradztwa Rolniczego No 1'17 (87), p. 46.

13. Skubiak, B. (2015). Czynniki i bariery rozwoju przedsiebiorczosci na obszarach wiejskich. (Factors and Barriers to Entrepreneurship Development in Rural Areas). Studia i Prace Wydziału Nauk Ekonomicznych i Zarzadzania, Uniwersytet Szczecinski, Nor 42, T.2, pp. 99-107.

14. Styk J. (1998). Chlopski swiat wartosci (Peasant World of Values), (In:) Socjologia wsi. Wybor tekstow i literatury socjologicznej. (Sociology of the Village. Selection of Sociological Texts and Literature), Zych R., (Ed.) Rzeszow: Wydawnictwo Wyzszej Szkoly Pedagogicznej, pp. 107-109.

15. Ustawa z dnia 22 pazdziernika 2004 r. o jednostkach doradztwa rolniczego (Dz. U. z 2004 r. Nr 251, poz. 2507, z pozn. zmianami). (Act of 22 October 2004 on Units of Agricultural Counselling. Journal of Laws no. 251, item 2507 as amended).

16. Wiatrak, A.P. (1998). Przedsiebiorczosc w strategii rozwoju gmin (Entrepreneurship in the Municipal Development Strategy), (In:) Agrobiznes w krajach Europy Srodkowej w aspekcie integracji z Unia Europejska (Agribusiness in the Countries of Central Europe in the Aspect of Integration with the European Union). Urban, S. (Ed.). Wroclaw: Wydawnictwo Akademii Ekonomicznej we Wroclawiu, p. 520. 